\title{
CENTRE-STATE RELATIONS IN INDIA
}

\author{
By A. G. Noorani
}

On March 13, 1975 the Central Cabinet placed the imprimatur of its endorsement on the view taken by the Administrative Reforms Commission that no changes in the Constitution of India are called for to ensure proper and harmonious Centre-State relations. The Cabinet felt, instead, that the existing provisions are adequate to meet any situation or resolve any problems that might arise between the Centre and the States ${ }^{1}$.

The Commission had submitted its Report as far back as June 19692. The Government of India's decision, which came as a surprise to nobody, was taken and publicised now because of the demand for greater autonomy voiced by the State of Tamil Nadu in the wake of the agreement announced on February 24, 1975 between Sheikh Abdullah and Prime Minister Indira Gandhi guaranteeing that the special status now enjoyed by the State of Jammu and Kashmir in the Indian Union, by virtue of Article 370 of the Constitution, will continue. Kashmir has far greater autonomy than any other State within the Union and is alone in having its own Constitution for State Government. Sheikh Abdullah had already abandoned categorically the demand for plebiscite but insisted that the State's unique position be recognised. History and geography have, both, collaborated to invest it with a distinctiveness.

But, the ruling party in Tamil Nadu, the Dravida Munnetra Kazhagam (DMK) also long abandoned the plea for the South's secession from the Union and feels its claim for greater autonomy should not be brushed aside. It is not much impressed by the argument that Kashmir had acquired an international dimension which the recent accord, it is hoped, will finally eliminate. The Tamil Nadu Chief Minister misses no opportunity for pressing his case. Presenting the budget to the State Assembly on March 1, 1975 he called for a "radical restructuring" of the financial relations between the Centre and the States. "Our difficulties arise from the fact that our fiscal powers are limited, we do not receive our due share in the national resources and we have no voice in the management of the national economy ${ }^{3}$."

A few days later he revived the States's claim to a separate flag.

While Mr. M. Karunanidhi is not altogether alone in voicing disquiet at the powers wielded by the Centre, he does not have much company, either. This is because his is the only State Government which is not run by the ruling party at the Centre, the Congress. The whole issue of Centre-State relations came to the fore only in 1967 when the general election held that year resulted in non-Congress Governments in some states, including the DMK in Tamil Nadu. The era of oneparty dominance the country had experienced seemed over. The President of India said in his address to Parliament that year, "For the first time since independence, governments of political complexions different from that of the Government at the Centre have been formed in several States. In a federal democratic polity this is to be expected. Our Constitution has provisions defining and regulating the relationship between the Union and the States and their mutual obligations.

1 The Hindustan Times March 14, 1975.

2 Report on Centre-State Relationships; Administrative Reforms Commission, Government of India,

New Delhi.

3 The Hindu March 2, 1975.

4 The Hindu March 13, 1975. 
Further, over the years we have developed certain institutions for promoting co-operation, understanding and harmonious relations between the Union and States, between one State and another. The National Development Council, the Zonal Councils and the periodic conferences of Governors and the Chief Ministers are conspicuous examples of this nature. The Union Government will respect the constitutional provisions in letter and spirit without any discrimination and endeavour to strengthen the arrangements for a co-operative approach to our national problems. We are sure that all States will extend their co-operation in serving these institutions and making their deliberations increasingly fruitful and beneficial both to the Union and to themselves."

Prime Minister Indira Gandhi herself told a conference of State Chief Ministers that year that she looked forward to a "more vigorous practising federalism with multiple parties and coalition in power". In a few years, however, the interlude ended leaving a trail of frustration. The coalitions broke up and Congress Ministries were formed in their place. The Congress Party tore itself apart in 1969 but Mrs. Gandhi emerged triumphant in the parliamentary election of 1971. During the election campaign for State legislatures she said, on February 3, 1972, that it was necessary that the State Governments should be "in tune" with the Government at the Centre, accept its policies, and be willing to implement its programme. Centre-State relations have a political as well as a constitutional aspect. In India the political aspect is more pronounced largely because of the Congress' virtual monopoly of power and the widespread feeling that the Central Government uses federal institutions for partisan ends and, especially so, the office of the Governor of State, who is nominated by the President of India on the advice of the Prime Minister, in order to instal in power a State Chief Minister belonging to the Congress Party wherever there is an option, constitutional proprieties regardless.

The Constitution of India endows the Centre with powers far greater than those possessed by any federal government and it would not be incorrect to say that it is based on a national consensus which has been shaped by the events of the last few decades and especially by the partition of India.

In the days of the British rule debate on the form of the Constitution of an independent India was influenced largely by the communal question. The AllIndia Muslim League demanded in 1929 that "the form of the future Constitution should be federal with the residuary powers vested in the provinces" and "a uniform measure of autonomy shall be granted to all provinces 5 ".

The Indian National Congress favoured a strong Centre, with safeguards for minority rights. Its views were well reflected in the Committee set up by an All Parties Conference on May 19, 1928, "to consider and determine the principles of the Constitution for India". The Committee was headed by Mr. Motilal Nehru. Its Report recommended a highly centralized federation enjoing all the residuary powers except those conceded to the Provinces ${ }^{6}$.

The communal deadlock was not resolved at the Round Table Conference convened in London by the British Government nor could agreement be reached on the association of the Indian States under the paramountry of the British Crown but governed by the old princely order. The British Government proposed a federation.

$5 \mathrm{Mr}$. M. A. Jinnah's famous 14 points. Pakistan movement. Historic Documents edited by G. Allana Karach; 1968; p. 70.

6 Vide Chapter VII emboding the recommendations of the Report; published by the General Secretary, All India Congress Committee, Allahabad, 1928. 
The Report of the Joint Committee of British Parliament on Indian Constitutional Reform noted that "Of course, in thus converting a unitary State into a federation, we should be taking a step for which there is no exact historical precedent. Federations have commonly resulted from an agreement between independent or, at least, autonomous governments, surrendering a defined part of their sovereignty or autonomy to a new Central organism. At the present moment the BritishIndian provinces are not even autonomous, for they are subject to both the administrative and legislative control of the Government of India and such authority as they exercise has been in the main devolved upon them under a statutory rule-making power by the Governor-General in Council. We are faced, therefore, with the necessity of creating autonomous units and combining them into a federation by one and the same Act. But it is obvious that we have no alternative. To create autonomous units without any corresponding adaptation of the existing Central Legislature would be, as the Statutory Commission say, to give full play to the powerful centrifugal forces of provincial autonomy without any attempt to counteract them and to ensure the continued unity of India." (Vol. I, Para 27.)

The Government of India Act, 1935 passed by the British Parliament sought to set up a federation which would grant autonomy to the provinces without endangering the country's unity. Because of lack of agreement with the political parties the federal part never came into operation, while the provinces did achieve responsible government and a certain measure of autonomy.

But the communal problem got exacerbated over the years and on March 23, 1940 the Muslim League passed the famous "Pakistan resolution" demanding India's partition on a religious basis.

This had a two fold effect on non-Muslim intelligentsia. On the one hand they favoured granting more substantial concessions to the Muslims in order to avert partition; on the other, awakened as they were now to this possibility, they favoured also a strong federation. This dichotomy is illustrated in the Constitutional Proposals of the Sapru Committee published in 1945. It was a non-official Committee headed by an eminent jurist, Sir Tej Bahadur Sapru. It went so far as to concede Muslims a representation at the Centre "on a par with the representation given to the Hindus (other than Scheduled Castes)" and other special interests such as industry, labour etc. It did not conceal its opinion that "a strong Centre was most necessary in India" and that its recommendations, including the a grudging concession of residuary rights to the Provinces, were offered only to buy peace.

Such reservations hardly help in evolving a compromise. The British Government sent a Mission to India consisting of three Cabinet Ministers to secure an agreement for the transfer of power.

The Mission's Proposals published on May 16, 1946, envisaged a union of India dealing with the subjects of defence, foreign affairs, and communications, with the residuary powers vesting in the provinces. There were to be three federal groups within the Union; one comprising of Punjab, N. W. Frontier Province and Sind, another of Bengal and Assam, and a third of the rest of the country. It was an ingenious device to have a Pakistan within the Indian Union. But conflicting interpretations led to the wreckage of the Plan?

7 See the author's essay "The Cabinet Mission and its Aftermath" in The Partition of India edited by C. H. Philips and Mary Doreen Wainwright; George Allen \& Unwin; London 1970. 
All that was left was a Constituent Assembly set up under the proposals which, once the proposals fell through, proceeded to draft the present Constitution of India, saddened by the trauma of partition and determined more than ever before on a strong Centre.

As it is even before the Plan fell through the Congress, which commanded a majority in the Constitution Assembly, was bent on stretching the Plan to the utmost to confer greater powers on the Centre than was legitimately its due. This influenced the Muslim League not a little in its attitude to the whole project. The Congress leaders invoked the doctrine of implied and inherent powers in support of their plans. The First Report of the Union Powers Committee submitted to the Constituent Assembly on April 17, 1947, reflected this approach.

On June 3, 1947, the British Government published the partition plan with the agreement of the League and the Congress. The Second Report of the Union Powers Comittee dated July 5, 1947, provides a most revealing glimpse of the outlook of the framers of the India's Constitution on Centre-State relations. "Momentous changes have since (April) occurred. Some parts of the country are seceding to form a separate State, and the plan put forward in the Statement of the 16th May on the basis of which the Committee was working is, in many essentials, no longer operative. In particular we are not now bound by the limitations on the scope of Union Powers. The first point accordingly that we considered was whether, in the changed circumstances, the scope of these powers should not be windened. We had no difficulty in coming to a conclusion on this point. The severe limitation on the scope of central authority in the Cabinet mission's plan was a compromise accepted by the Assembly much, we think, against its judgement of the administrative needs of the country, in order to accomodate the Muslim League. Now that partition is a settled fact, we are unanimously of the view that it would be injurious to the interests of the country to provide for a week central authority which would be incapable of ensuring peace, of co-ordinating vital matters of common concern and of speaking effectively for the whole country in the international sphere. At the same time, we are quite clear in our mind that there are many matters in which authority must lie solely with the Units and that to frame a constitution on the basis of a unitary State would be a retrograde step, both politically and administratively. We have accordingly come to the conclusion - a conclusion which was also reached by the Union Constitution Comittee - that the soundest framework for our constitution is a federation, with a strong Centre. In the matter of distributing powers between the Centre and the Units we think that the most satisfactory arrangement is to draw up three exhaustive lists on the lines followed in the Government of India Act of 1935, viz., the federal, the provincial, and the concurrent. We have prepared three such lists accordingly ... We think that residuary powers should remain with the Centre."

The Mission's proposals were accepted reluctantly and fell through because of the reservations. There would now be a federation because a unitary set up would be a "retrogade" step reminiscent of the Raj. Besides the Act 1935 had created the provincial politcian. But the federation will have a strong centre modelled on the Government of India Act, 1935. That is precisely what happened. The Constitution of India draws heavily on that Act and contributes its own features designed to make the Union strong and all-powerful. The wheel had come full circle. As far back as $1936 \mathrm{Mr}$. Jawaharlal Nehru had said "It is likely that 
free India may be a Federal India, though in any event there must be a great deal of unitary control ${ }^{8}$."

If the Constitution of the United States creates "an indestructible union, composed of indestructible States" as the Supreme Court said", the Constitution of India creates a "Union of States" in which the very existence of the States is at the mercy of the Union. Under Article 3 of the Constitution Parliament may by ordinary law, without any constitutional amendment, form new States, increase or diminish the size of any State, alter its boundaries, partition or unite States. The consent of the State affected is not necessary. The only right its legislature has is of "expressing its views" on the Bill.

The head of States is the Governor. His status, it is true, is that of a constitutional head in a parliamentary democracy and executive power belongs to the Council of Ministers headed by the Chief Minister. But the Governor is appointed by the President of India, on the Prime Minister's advice, and (Art. 156 [1]) holds office "during the pleasure of the President". Ordinarily he has a five years term.

It is a peculiar position, for the Governor can become an agent of the President. Yet, he is a constitutional head of whom a high degree of rectitude and impartiality are expected. Much of the resentment at the Centre's predominance is inspired by the justified feeling that it has instructed and used the Governors to promote the Congress Party's interests. Of this, more by and by.

The division of legislative power is modelled on that in the Act of 1935. There are three lists enumerating subjects of legislation, namely, Union, State and a Concurrent one on which both may legislate. The legislative supremacy of the Union is embodied in Article 246 which reads thus: "(1) Notwithstanding anything in clause (2) and (3), Parliament has exclusive power to make laws with respect to any of the matters enumerated in List I in the Seventh Schedule (in this Constitution referred to as the "Union List").

(2) Notwithstanding anything in clause (3), Parliament, and, subject to clause (1), the Legislature of any State also, have power to make laws with respect to any of the matters enumerated in List III in the Seventh Schedule (in this Constitution referred to as the "Concurrent List").

(3) Subject to clauses (1) and (2), the Legislature of any State has exclusive power to make law for such State or any part thereof with respect to any of the matters enumerated in List II in the Seventh Schedule (in this Constitution referred to as the "State List").

(4) Parliament has power to make laws with respect to any matter for any part of the territory of India not included (in a State) notwithstanding that such matter is a matter enumerated in the "State List".

The result is not much different from what judicial decisions in the US and Canada and S. 109 of the Commonwealth of Australia Act have achieved. Article 72 (1) of the Grundgesetz of the Federal Republic of Germany, likewise, lays down that "in matters within concurrent legislative powers the Laender shall have power to legislate as long as, and to the extent that the Federation does not exercise its right to legislate", though sub-clause (2) lays down certain restrictions on the exercise of the Federation's right to legislate on these matters, initially.

The residuary powers of legislation vest in the Union as in Canada and unlike the US, Australia, and the Federal Republic of Germany. 
But under Article 249 if the Council of States, (Rajya Sabha) the Upper House of Parliament, "has declared by a resolution supported by not less than two-thirds of the members present and voting that it is necessary or expedient in the national interest that Parliament should make laws with respect to any matter enumerated in the State List specified in the resolution, it shall be lawful for Parliament to make laws for the whole or any part of the territory of India with respect to that matter while the resolution remain in force. A resolution passed under clause (1) shall remain in force for such period not exceeding one year as may be specified therein:

Only three resolutions have been passed under this Article leading to the enactment of the Essential Supplies (Temporary Powers) Amendment Act. 1950, the Supply and Prices of Goods Act, 1950, and the Evacuee Interest (Separation) Act, 1951. But the basis of the provision, namely, that the Council of States represent State interests is debatable. Members of the Council are elected by the State legislatures and the States representation is on the basis of population. If there is a difference of opinion between the lower house, the House of the People (Lok Sabha) and Rajya Sabha, the President is empowered to convene a joint sitting of both to resolve the issue by a majority of members of both. A Money Bill may not be introduced in the Rajya Sabha. That apart, it has none of the special functions of the US Senate nor are its members representative of the State Governments as members of the Bundesrat of the Federal Republic of Germany are (Art. 51 of the Grundgesetz).

Moreover, once a Proclamation of Emergency is promulgated by the President, Parliament is empowered to legislate on matters in the State list as well. India becomes a unitary State. A Proclamation may be made "If the President is satisfied that a grave emergency exists whereby the security of India or of any part of the territory thereof is threatened, whether by war or external aggression or internal disturbance."

Likewise Parliament may legislate on a matter in the State List to give effect to any treaty or Convention. The States are autonomous within the sphere allotted to them, but not fully. For the Governor may reserve a Bill passed by the State Assembly for the consideration of the President (Arts. 200 and 201) who may withhold assent or send the Bill back for reconsideration.

The executive power of, both, the Union and the States is co-extensive with their respective legislative powers. But, with a difference. The Centre has the power to issue directives in certain cases. Thus, Art. 256 provides "The executive power of every State shall be so exercised as to ensure compliance with the laws made by Parliament and any existing laws which apply in that State, and the executive power of the Union shall extend to the giving of such directions to a State as may appear to the Government of India to be necessary for that purpose."

Article 257 (1) "The executive power of every State shall be so exercised as not to impede or prejudice the exercise of the executive power of the Union, and the executive power of the Union shall extend to the giving so such directions to a State as may appear to the Government of India to the necessary for that purpose.

"(2) The executive power of the Union shall also extend to the giving of directions to a State as to the construction and maintenance of means of communication declared in the direction to be a national or military importance: 
Provided that nothing in this clause shall be taken as restricting the power of Parliament to declare highways or waterways to be national highways or national waterways of the power of the Union with respect to the highways or waterways so declared or the power of the Union to construct and maintain means of communication as part of its functions with respected to naval, military and air force works."

"(3) The executive power of the Union shall also extend to the giving of directions to a State as to the measures to be taken for the protection of the railways within the State."

These provisions are necessary because the Centre mainly depends on the States, for the enforcement of the laws. Its own law-enforcement machinery is slender.

The consequences of recalcitrance on the part of the States are spelt out clearly in Art. 365 "Where any State has failed to comply with, or to give effect to, any directions given in the exercise of the executive power of the Union under any of the provisions of this Constitution, it shall be lawful for the President to hold that a situation has arisen in which the government of the State cannot be carried on in accordance with the provisions of this Constitution."

This is a step towards the imposition of Central Government's rule on the State, popularly called President's rule. But the President of India, as constitutional head, acts on the Union Cabinet's advice. Article 356 lays down the procedure for the drastic step:

"(1) If the President on receipt of a report from the Governor of a State or otherwise, is satisfied that a situation has arisen in which the government of the State cannot be carried on in accordance with the provisions of this Constitution, the President may be Proclamation -

(a) assume to himself all or any of the functions of the Government of the State and all or any of the powers vested in or exercisable by the Governor or any body or authority in the State other than the Legislature of the State;

(b) declared that the powers of the Legislature of the State shall be exercisable by or under the authority of Parliament;

(c) make such incidental and consequential provisions as appear to the President to be necessary or desirable for giving effect to the objects of the Proclamation, including provisions for suspending in whole or in part the operation of any provisions of this Constitution relating to any body or authority in the State:

Provided that nothing in this clause shall authorise the President to assume to himself any of the powers vested in or exercisable by a High Court, or to suspend in whole or in part the operation of any provision of this Constitution relating to High Courts.

(2) Every Proclamation may be revolked or varied by a subsequent Proclamation.

(3) Every Proclamation under this article shall be laid before each House of Parliament and shall, except where it is a Proclamation revoking a previous Proclamation, cease to operate at the expiration of two months unless before the expiration of that period it has been approved by resolutions of both Houses of Parliament."

To complete the picture, one should bear in mind Article 355 which lays down that "it shall be the duty of the Union to protect every State against external aggression and internal disturbances and to ensure that the government of every State is carried on in accordance with the provisions of this Constitution." 
It is not difficult to see that the working of this scheme requires of the Centre a certain restraint and of the Governors manifest impartiality. This is not to deny the duties of the States; but their powers are limited and correspondingly, the temptation to excess. It is only to emphasise the need for greater rectitude where the greater power resides.

The Union Home Ministry had occasion on November 8, 1967 to remind the States of their duty to protect the Central installations and agencies. "If the work of such agencies is frequently interfered with by organised groups of people and the State Governments refuse to take, or obstain from taking effective measuresto prevent and deal with such interference, not only would the State Government be failing in the discharge of its obligations under the Constitution but the entire basis of the administrative structure, envisaged by the Constitution, would be seriously undermined."

Another reminder had to be sent to the Communist Government of Kerala in 1968 when Central Government employees went on strike. If, as in 1967, the political complexion of several State Governments differs from that at the Centre, it may be that more such cases might arise.

But, ordinarily, it is the office of the Governor which is regarded as a link between the States and the Union Governments to iron out potential differences. Yet, his office does require that in the working of the State Constitution he must hold the seales evenly. This has not been done. In October 1973 the Orissa High Count criticised the Governor for recomending President's rule when there was no need to.

The ARC'S Report took note of the critcisms made against the Governors in 1967 when for the first time they were called upon to take difficult decisions such as selection of the Chief Minister, amidst conflicting claims to majority support in the Assembly, the summoning of the legislature when its support to the Ministry was uncertain, dissolution of the legislature on the advice of a Chief Minister who has lost its support, and the like. It recommended that "A person to be appointed as a Governor should be one who has had a long experience in public life and administration and can be trusted to rise above party prejudices and predilections. He should not be eligible for further appointment as a Governor after the completion of his term."

In 1970 the Annual Conference of Governors appointed a Committee consisting of five of themselves "to study and formulate norms and conventions governing the role of Governors under this Constitution." The Report of the Committee of Governors (1971) covers a wide field. On the aspect of Centre-State relations its most noteworthy contribution lies in the enunciation of the principle that "the Governor, as Head of the State, has his functions laid down in the Constitution itself, and is no sense an agent of the President." If this principle is observed an obstacle to harmonious Centre-State Relations will have been removed.

For it must not be thought that resentment of the Governor's undue deference to the Centre is confined only to non-Congress Chief Ministers. Those belonging to the ruling party have also chafed at it. In 1956 the boundaries of the States were redrawn on the linguistic basis under the States Reorganization Act, 1956. State feelings and animosities run high especially on border and river disputes.

The Constitution (Art. 262) makes the Centre the virtual arbiter in them. "Parliament may by law provide for the adjudication of any dispute or complaint with respect to the use, distribution or control of the waters of, or in, any inter- 
State river or river valley." So do the laws passed by Parliament in this regard such as the River Boards Act 1956 and the Inter-State Water Disputes Act, 1956. The Zonal Councils set up under the States Reorganization Act, 1956 are chaired by a Central Ministers. But the Centre has long dithered over river disputes and longer over the border rows. The Maharashtra-Mysore border dispute is unresolved for nearly two decades. The reason is simple. The leaders of the Government of India use the party machinery instead of the institutions set up by the Constitution and the law to resolve inter-State disputes because both the disputants States happen to be ruled by Congress Government.

There can be no more telling instance of the Centre's neglect than its failure to this day to establish an inter-State Council contemplated by Article 263 of the Constitution: "If at any time it appears to the President that the public interests would be served by the establishment of a Council charged with the duty of -

(a) inquiring into and advising upon disputes which may have arisen between States;

(b) investigating and discussing subjects in which some or all of the States, or the Union and one or more of the States, have a common interest; or

(c) making recommendations upon any such subject and, in particular, recommendations for the better co-ordination of policy and action with respect to that subject,

it shall be lawful for the President by order to establish such a Council, and to define the nature of the duties to be performed by it and its organisation and procedure."

The ARC had strongly recommended the establishment of such a Council. Such failure of Centreal leadership in a highly centralized polity is bound to impair its strength particularly when in other aspects there is a strong feeling that the Centre has not exercised its powers in a non-partisan spirit.

On September 22, 1969 the Tamil Nadu Government appointed a Committee "to examine the entire question regarding the relationship that should subsist between the Centre and the States in a federal set up, with reference to the provisions of the Constitution of India, and to suggest suitable amendments to the Constitution so as to secure to the States the utmost autonomy."

Unfortunately the Report of this Centre-State Relations Inquiry Committee is concerned not so much to pin-point the defects in the Constitution, revealed by experience, as simply to suggest measures "to secure to the States the utmost autonomy". The Report's recommendations are, but a series of amendments designed to mould the Indian Constitution on the American model. A fine opportunity was missed in this wasteful exercise.

It is clear that a serious review of Centre-State relations in India is called for in the light of a quarter century's experience of the working of the Constitution. But the terms of reference for such a review will be of fundament importance. It should be based on Indian experience and seek to answer Indian needs, basically. Only in this context can references to the other federations be helpful.

Primarily, the problem of Centre-State relations in India is political rather than constitutional. The single-Party dominance, the failure to evolve a credible Opposition at the Centre, and the crisis of political morality lie at the root of the present frustrations.

This is not to deny the existence of genuine constitutional disputes. The validity of the Central Reserve Police, Act, 1949, for instance, has been the subject of 
conflicting High Court decisions. The issue is yet to be resolved by the Supreme Court. The growth of extra-Constitutional bodies like the Planning Commission affords a genuine cause for disquiet. It has no statutory basis and owes its existence to a resolution of the Government of India. Besides, there is much room for decentralisation. The ARC's recommendation in this regard is helpful. "Powers should be delegated to the maximum extent to the States with regard to their work on projects in which the Centre is directly interested or which are carried out by them as agents to the Central Government".

It is unfortunate that no attempt has been made yet to review the distortions in a system which undoubtedly commends wide acceptance. It is not only the ARC which holds that "No Constitutional amendment is necessary for ensuring proper and harmonious relations between the Centre and the States, inasmuch as the provisions of the Constitution governing Centre-State relations are adequate for the purpose of meeting any situation or resolving any problems that may arise in this field."

Even a critic of the Government like the former leader of the Indian Bar, the late Mr. M. C. Setalvad, who was India's Attorney-General from 1950 to 1962, has expressed the view that "possibly under the stress of recent pressures one is witnessing not a move towards a powerful Centre but an attempt at a virtual control of the States by the Centre. It is difficult to say that this is a healthy development. One view would seem to hold this necessary and useful to the rapid attainment by our country of its appointed goal. Many however regard it as a political manoeuvre which distorts the Constitution and deprives the constituent Units of such autonomy as the Constitution has conferred on them. However that may be there is little doubt that we have to move in some manner towards more and more power and control by the Centre.

"May I conclude by saying that such increased power in he Centre need not mean an end to all autonomy in the States? Perhaps after the present stresses and strains have passed we may settle down to a more balanced working of our constitutional system under which the Centre though powerful and in general control may yet leave to the States such autonomy as the Constitution-makers thought it right to leave to them. That is the way to achieve what has been called 'cooperative federalism'".10

Mr. Setalvad is moved as much by a concern for the country's economic development as by nationalistic fervour. The present pattern of Centre-State relations must be viewed against this background.

The American colonies who formed a federation two centuries ago were free agents. Even so, they went through the experience of the Articles of Confederation of 1781 before adopting the Constitution in 1789. The American Civil War influenced the draftsmen of the British North America Act, 1867 which embodies the Canadian Constitution. It establishes a much more centralized polity than that of the US. The Commonwealth of Australia Constitution Act, 1900 on the other hand, is closer to the American model. Common to them all is the role of the judiciary as the umpire between the Centre and the States.

The framers of the Indian Constitution drew from all three. Unfortunately they overlooked completely the masterpiece of constitutional craft which the Grundgesetz of the Federal Republic of Germany is. It was adopted by the Parliamentary

10 Union and State Relations under the Indian Constitution; Eastern Law House, Calcutta, 1974; p. 6. 
Council on May 23, 1949 while the Constituent Assembly of India was still engaged in its task. But the Council's deliberations, which began on September 1, 1948, went wholly unnoticed. The neglect continues still, which is a pity.

For the Grundgesetz is more relevant to the Indian predicament than any of the other three models. Article 91 (2) on Federal intervention to avert danger to "the free democratic basic order of the Federation or a land", though more circumscribed than Art. 365 of the Indian Constitution, nonetheless reflects a common fear. On the other hand Article 91 a on execution of joint tasks by the Federation and the Laender is a creative amendment (of May 12, 1969) which India constitutionalists can well reflect on. It is an example of "co-operative federalism" which is what India needs badly today. It calls for little constitutional change. It demands largely a change of approach particularly on the part of the Centre and that will suffice to remove the present feeling of frustration in the States. 